\title{
МІСЬКЕ САМОВРЯДУВАННЯ У ВЕЛИКОБРИТАНІЇ: ПОЯВА СУЧАСНОї КОНЦЕПЦІї
}

Hecmop B. P.

Метою статті $\epsilon$ аналіз історичного досвіду міського самоврядування у Сполученому Королівстві в контексті британської муніципальної революції.

Нині в Україні відбувається муніципальна реформа. Вона привертає увагу до вивчення історичного досвіду - як національного, так і історичного. 3 точки зору активізації процесів урбанізації цікавим $\epsilon$ історичний досвід міського самоврядування.

Iсторичний період, якій $\epsilon$ цікавим у розвитку міського самоврядування як в Україні, так і у Сполученому Королівстві, - це формування місцевого самоврядування у його сучасному вигляді. Варто зазначити, що цей історичний період охоплює надзвичайно тривалий проміжок часу - від «британської муніципальної революції XIX століття» до деволюції публічної влади, яка відбулася наприкінці XX - на початку XXI століть. Наприкінці XIX століття сформувались органи міського управління, які функціонують і досі, а компетенційна та економічно-фінансові основи їхньої діяльності були закладені під час здійснення деволюції. Так само деволюція внесла і певні зміни в те, яким чином здійснюється міське самоврядування в різних історичних частинах Сполученого Королівства.

За часів феодалізму кожне британське місто розвивалося в напрямі чи напрямах, які вважалися більш доцільними з точки зору його географічних, культурних, інших особливостей його найбільш заможними мешканцями. Індивідуалізація міського самоврядування знаходила свій прояв не в організаційно-правових формах (тобто не через структуру міського самоврядування), як у більшій частині міст континентальної Європи.

Варто зазначити, що занепад феодалізму та промислова революція сприяли тому, що в середині XIX століття у Сполученому Королівстві почалася масштабна муніципальна реформа, яка тривала практично до кінця сторіччя та отримала назву «британська муніципальна революція».

Попри значущість «британської муніципальної революції» як всеохоплюючої реформи місцевого, у т.ч. міського самоврядування, варто зазначити, що вона модернізувала феодальні інститути таким чином, щоб вони відповідали потребам розвитку науки, техніки, технологій, капіталістичного укладу економіки. Запроваджена у процесі цієї реформи

(c) Нестор B. P., 2020 система проіснувала майже століття і була піддана критичному та системному перегляду лише у 1970-х роках.

Перспективи подальших досліджень у цьому напрямі вбачаються в аналізі попереднього та наступних історичних періодів розвитку міського самоврядування у Сполученому Королівстві Великобританії і Північної Ірландії.

Ключові слова: міське самоврядування, місцеве самоврядування, місто, міська територіальна громада, територіальна громада, публічна влада.

Nestor V. R. City government in the United Kingdom: the modern concept's appearance

The aim of the article is to analyze the historical experience of urban self-government in the United Kingdom in the context of the British municipal revolution.

Ukraine is currently undergoing municipal reform. It draws attention to the study of historical experience - both national and historical. From the point of view of intensification of urbanization processes, the historical experience of city self-government is interesting.

The historical period that is interesting in the development of urban self-government both in Ukraine and in the United Kingdom is the formation of local self-government in its modern form. It is worth noting that this historical period covers an extremely long period of time from the "British municipal revolution of the nineteenth century" to the devolution of public power, which took place in the late twentieth - early twenty-first century. At the end of the XIX century, city government bodies were formed, which still function, and the competence and economic and financial foundations of their activities were laid during the devolution. Similarly, the devolution has brought some changes to the way in which urban self-government is exercised in various historical parts of the United Kingdom.

Under feudalism, every British city developed in a direction or directions that were considered more appropriate in terms of its geographical, cultural and other features of its wealthiest inhabitants. The individualization of urban self-government did not manifest itself in organizational and legal forms (that is, not through the structure of urban self-government), as in most cities of continental Europe.

It should be noted that the decline of feudalism and the industrial revolution contributed to the large-scale 
municipal reform in the United Kingdom in the mid-nineteenth century, which lasted almost until the end of the century and was called the "British Municipal Revolution".

Despite the importance of the "British Municipal Revolution" as a comprehensive reform of the local, including urban self-government, it should be noted that it modernized the feudal institutions so that they meet the needs of science, technology, technology, capitalist economy. The system introduced during this reform lasted for almost a century, and was subjected to critical and systematic revision only in the 1970s.

Prospects for further research in this area are seen in the analysis of previous and subsequent historical periods in the development of urban self-government in the United Kingdom of Great Britain and Northern Ireland.

Key words: city government, local government, city, city territorial community, territorial community, public authority.

Постановка проблеми та їі актуальність. Нині в Україні відбувається муніципальна реформа. Вона привертає увагу до вивчення історичного досвіду - як національного, так і історичного. 3 точки зору активізації процесів урбанізації цікавим $є$ історичний досвід міського самоврядування.

Історичний період, якій $є$ цікавим у розвитку міського самоврядування як в Україні, так і у Сполученому Королівстві, - це формування місцевого самоврядування у його сучасному вигляді. Варто зазначити, що цей історичний період охоплює надзвичайно тривалий проміжок часу - від «британської муніципальної революції XIX століття» до деволюції публічної влади, яка відбулася наприкінці XX - на початку XXI століть. Наприкінці XIX століття сформувались органи міського управління, які функціонують і досі, а компетенційна та економічно-фінансові основи їхньої діяльності були закладені під час здійснення деволюції. Так само деволюція внесла і певні зміни в те, яким чином здійснюється міське самоврядування в різних історичних частинах Сполученого Королівства.

Варто зазначити, що занепад феодалізму та промислова революція сприяли тому, що у середині XIX століття у Сполученому Королівстві почалася масштабна муніципальна реформа, яка тривала практично до кінця сторіччя та отримала назву «британська муніципальна революція».

Аналіз останніх досліджень i публікацій. Питання міського самоврядування у Сполученому Королівстві Великобританії і Північної Ірландії у порівняльному контексті з Україною поки що не аналізувалися. Що ж до питань компаративного дослідження місцевого самоврядування у цих країнах загалом, то воно розроблялось лише про- фесором Н.В. Мішиною [1-3]. Однак вона не публікувала праці, присвячені історії самоврядування в цій країні, у т.ч. про британську муніципальну революцію.

Метою статті $є$ аналіз історичного досвіду міського самоврядування у Сполученому Королівстві в контексті британської муніципальної революції.

Виклад основного матеріалу. У середньовіччі британські міста мали королівські хартії самоврядування, однак ці хартії надавали вкрай мало прав і свобод. Поступово ситуація змінювалася на краще для міст - так, у 1200 році таун Іпсвіч отримав привілей, відповідно до якого бейліф та коронер не призначувались монархом, а обирались мешканцями міста. Однак такі випадки були поодинокими. Здебільшого в місцевих населених пунктах мешканці формували невелику за своєю чисельністю раду, обирали голову (мера) та інколи тих посадових осіб, яких мали право обирати відповідно до своєї хартії.

Інколи з метою економії ресурсів міста, навпаки, свідомо відмовлялись від змоги формувати власні органи, обирати власних посадових осіб. Так, хрестоматійним прикладом став досвід міста Лестер, в якому королівський суд водночас функціонував як суд міської гільдії купців цього міста (за дозволом монарха) [4, с. 742].

Вчені узагальнюють інформацію про міське самоврядування у середньовіччі щодо Сполученого Королівства, констатуючи, що «зросла роль міст у соціально-економічному та політичному житті країни. Міста були крупними платниками податків. Вони давали королям грошові субсидії. Натомість королівська влада давала містам різні привілеї. Приблизно 200 міст Британії мали у XIII ст. міські хартії, що давали їм економічні та політичні права і вольності. Міста, як і раніше, залишались вірними союзниками монарха» [5, с. 26].

Дослідники пропонують вважати, що у Сполученому Королівстві «до перших актів, що стосуються діяльності місцевого самоврядування, можна зарахувати королівські хартії про інкорпорацію. Ці документи давали самостійність окремим містам, в яких:

1) створювалися свої органи влади;

2) формувалася внутрішньоміська судова система;

3) визначалася власність, що належала місту» $[6$, c. 88].

Варто погодитись із цим твердженням частково. Дійсно, вчені справедливо окреслили коло питань, які містили королівські хартії для міст. Однак передчасно було б іменувати ці хартії «хар- 
тіями про інкорпорацію». Справа у тому, що це поняття застосовується на сучасному етапі для того, щоб відмежовувати інкорпоровані адміністративно-територіальні одиниці (муніципалітети) від адміністративно-територіальних одиниць, які не $\epsilon$ інкорпорованими (тобто не уважаються муніципалітетами). Таким чином, хартії британських монархів, що надавалися містам, навряд чи можуть вважатися актами про інкорпорацію адміністративно-територіальної одиниці.

Варто зазначити, що з часом королівські хартії почали «цікавити» лише ті міські населені пункти, де були утворені купецькі гільдії, адже хартії надавали здебільшого фінансово-економічні привілеї. Як зазначають дослідники історії держави і права Сполученого Королівства, «ще з часів династії Плантагенетів англійські міста мали можливість стати «самостійними», відкупившись від повинностей на користь короля і помісних лордів» [7, с. 55]. Варто погодитись із таким ємним та стислим визначенням сутності королівських хартій для британських міст.

Таким чином, кожне британське місто розвивалося в напрямі чи напрямах, які вважалися його найбільш заможними мешканцями більш доцільними з точки зору його географічних, культурних, інших особливостей. Індивідуалізація міського самоврядування знаходила свій прояв не в організаційно-правових формах (тобто не через структуру міського самоврядування), як у більшій частині міст континентальної Європи. Перевага віддавалася функціональному, компетенційному розвитку - ті кошти, які залишались у місцевих бюджетах після сплати податків та зборів до Державної казни, застосовувались на подальший розвиток міста (або городяни, їхнє майно обтяжувалися податками значно менше, ніж сільські жителі, а тому мали вищий рівень життя).

Доволі красномовно необхідність змін у державному управлінні та у місцевому самоврядуванні на цьому етапі історичного розвитку з філософської точки зору описав С.О. Капков: «Розвиток капіталізму, науково-технічна революція, індустріалізація та урбанізація в останній третині XIX століття ознаменували початок нової епохи, яку називають епохою модерну (modernity). Маховик прогресу в західних містах, який розкручувався з епохи Відродження, привів до найбільш радикального розриву сучасного життя $з$ життям у традиційних суспільствах. Круто змінилися ритм і мобільність» [8, с. 46].

Британська муніципальна революція почалася у доволі важких соціальних умовах, на стиці феодалізму та капіталізму. Як зазначають фахівці з історії держави і права, «початок XIX ст. характеризується прагненням землевласницької аристократії всіляко зберегти себе як клас, однорідний у своїх державних і суспільних інтересах і поглядах. Разом із тим у процесі промислової революції перетворення Великобританії з країни землеробської на найбільшу торгівельно-промислову державу світу не могло не привести до корінних змін у взаєминах населення, в суспільній структурі нації і у всіх іï історичних традиціях. Соціальна основа життя Англії істотно змінилася. Сталося переміщення значної частини населення до міст і посилилося економічне значення індустріальних і торговельних класів, керівна роль землевласницької аристократії в політиці і самоврядуванні ставала неможливою» [9, с. 115].

Нормативно-правовим актом, з якого почалась британська муніципальна революція, став Акт про муніципальні корпорації 1835 року (у цьому Акті було закріплено вимогу про виборність членів цих корпорацій - фактично, муніципальних рад, а також впроваджувалась система цих рад). Прийняття цього документа активно лобіювалось британськими містами, особливо крупними центрами промисловості та капіталу.

О.В. Чумакова, досліджуючи історичні обставини впровадження цього Акта для британських міст, зазначила: «У 1835 р. у містах Великобританії було здійснено спробу створення відокремленого управління на місцях, результатом якої стало формування повноцінної системи міського самоврядування» [10, с. 97]. Як підкреслюють фахівці з історії держави і права, «фактично, це був перший правовий акт, який замінив партикулярні норми грамот і хартій, які регулюють кожне місто окремо» [6, с. 88-89]. Починаючи з цього часу, коректніше говорити, що конкретна адміністративно-територіальна одиниця $\epsilon$ інкорпорованою, тобто $€$ муніципалітетом. Однак міське самоврядування поки що не набуло своїх сучасних рис, це відбувалося поступово.

Майже через 50 років було впроваджено повністю виборні представницькі органи місцевого самоврядування: «Відповідно до закону “Про місцеве управління” у 1888 р. у країні почали обиратися ради графств, на які покладався обов'язок підтримання в належному стані доріг, забезпечення притулків для бездомних і дітей, керівництво поліцією. Створеним у графствах виборним радам була передана вся адміністративна влада. У результаті реформи місцеве самоврядування перейшло від аристократії до підприємців» [10, с. 97-98]. 
Завершення реформи, на думку дослідників, знаменували акти про місцеве управління 1888 та 1894 років, а також Акт про управління Лондону 1899 року.

Потреба у прийнятті Акта про місцеве управління 1894 року майже через п'ять років після набуття чинності Актом про місцеве управління 1888 року полягала у факті, якій є цікавим для дослідників британського міського самоврядування, - у необхідності впровадити різні підходи до організації місцевого самоврядування в сільських та міських населених пунктах. Органи місцевого самоврядування в сільських населених пунктах були визнані необхідними (до цього часу вони були далеко не в кожному селі, а відповідні функції покладались на муніципальні органи графств). Варто зазначити, що органи сільського самоврядування мали значно менше коло повноважень, ніж органи самоврядування в міських населених пунктах, а їхня фінансово-економічна база була доволі скромною. Це можна пояснити відсутністю вагомого впливу в «старих еліт» - британської аристократії.

Акт про управління Лондону 1899 року як такий, що завершив «британську муніципальну революцію», є особливо символічним - із початком промислової революції у Сполученому Королівстві дедалі більше прав та повноважень концентрувалося у британських містах, у т.ч. в Лондоні. Вплив міст, у т.ч. економічний, постійно зростав, що й знайшло своє відображення в ідеології реформи місцевого самоврядування в містах. Протягом «британської муніципальної революції» самоврядування в британських містах поступово набувало сучасних рис. Представники еліти, що проживали в містах, ефективно лобіювали власні інтереси, як наслідок, вчені справедливо узагальнюють, що «муніципальна революція» XIX ст., що проводилася в Великобританії поетапно, становила особливий інтерес, тому що вікторіанці, демократизуючи державний устрій, зробили ставку в реформі місцевого управління на місцевий інтерес, ініціативу, відповідальність, що в усі часи становило суть англійського selfgovernment ${ }^{1}$. Воно своєю чергою оцінювалося як основа парламентського правління в Великобританії» [11, с. 75]. Наголос на правах людини, у т.ч. на політичних правах, органічне поєднання відстоювання народного представництва на загальнодержавному та на місцевому рівнях сприяли успіху реформ місцевого, у т.ч. міського самоврядування. Історики підкреслюють, що ця «реформа місцевого управління

\footnotetext{
3 англ. місцеве самоврядування. - В. Н.
}

виявилася неминучою на тому етапі політичної еволюції Британії, коли здійснювався перехід від олігархічного правління до реальної конституційної демократії» [11, с. 78].

Варто зазначити, що саме ця муніципальна реформа - «британська муніципальна революція» - привернула увагу відомого фахівця з місцевого самоврядування, професора Р. Гнейста. Перебуваючи у постійних наукових пошуках, «Р. Гнейст займався історією Британії, з його точки зору, класичної країни буржуазного конституціоналізму, бо намагався знайти модель для найкращого політичного устрою Пруссії, а пізніше - Німецької імперії. Він не обмежився простим викладом історичного розвитку внутрішнього управління і сформулював власну теорію selfgovernment ${ }^{2}$ як характерної для Англії організації внутрішньої державної влади. Він захоплювався «англійською свободою», втілення якої бачив у тисячолітній історії парламенту. Головним джерелом цієї свободи він вважав систему selfgovernment. Вона впродовж століть ніби підпирала весь розвиток центральних установ країни і визначила своєрідність національного розвитку, який різко відрізнявся від того шляху, яким слідували держави континенту» [11, с. 79]. Варто зазначити: попри те, що Р. Гнейст був знавцем муніципального досвіду Сполученого Королівства, він не вважав його прийнятним для запозичення Німеччиною. Формулюючи висновки та пропозиції для організації місцевого (комунального) самоврядування в Німецькій імперії, Р. Гнейст застосував державницьку теорію місцевого самоврядування, а не теорію вільної громади, на якій ґрунтується місцеве, у т.ч. міське самоврядування, в Сполученому Королівстві від свого виникнення до теперішнього часу.

Висновки. Попри значущість «британської муніципальної революції» як всеохоплюючої реформи місцевого, у т.ч. міського самоврядування, варто зазначити, що вона модернізувала феодальні інститути таким чином, щоб вони відповідали потребам розвитку науки, техніки, технологій, капіталістичного укладу економіки. Запроваджена в процесі цієї реформи система проіснувала майже століття і була піддана критичному та системному перегляду лише в 1970-х роках.

Перспективи подальших досліджень у цьому напрямі вбачаються в аналізі попереднього та наступних історичних періодів у розвитку міського самоврядування в Сполученому Королівстві Великобританії і Північної Ірландії.

2 «Самоврядування» англійською мовою. - В. Н. 


\section{Література}

1. Мішина Н.В. Територіальні громади та об'єднані територіальні громади в Україні. Наукові праці НУ ОЮА. 2019. Т. 24. С. 75-80.

2. Мішина Н.В. Актуальні проблеми викладання муніципального права в Україні. Наукові праці НУ ОЮА. 2016. Т. 15. С. 161-167.

3. Мішина Н.В. Деякі особливості муніципального управління в Лондоні. Актуальні проблеми держави і права: Збірник наук. праць. Вип. 22. Одеса : Юридична література, 2004. С. 229-233.

4. Karn N. Centralism and Local Government in Medieval England: Constitutional History and Assembly Politics, 950-1300. History Compass. 2012. \# 10. P. 742-751.

5. История стран Западной Европі в 2 ч. Часть 1. Великобритания. Германия : учебник для академического бакалавриата. Москва: Изд-во Юрайт, 2019. 356 c.

6. Пшенко О.Ю., Пшенко А.Г. Формирование модели местного самоуправления в Великобритании (исторический аспект). Историческая и социально-образовательная мысль. 2014. № 6-1. С. 88-91.
7. Евдокимов В.Б., Старцев Я.Ю. Местные органы власти зарубежных стран: правовые аспекты. Москва : Спарк, 2001. 251 с.

8. Капков С.А. Трансформация городских общественных пространств (социально-философские аспекты) : дис. ... канд. философ. наук. Москва, 2020. 198 c.

9. Горбатюк Е.С. Местное самоуправление в Великобритании XIX в.: аналитический обзор. Вестник Санкт-Петербургского университета. Политология. Международные отношения. 2010. № 1. С. 113-120.

10. Чумакова О.В. Шляхи розвитку місцевого самоврядування України в контексті досвіду держав Європейського Союзу : дис. ... канд. держ. упр. Дніпропетровськ, 2008. 200 с.

11. Дребушевская Г.А. Феномен английского самоуправления. Вестник Омского университета. 2009. № 1. С. 75-80.

Hecmop B. P., кандидат юридичних наук 